\title{
(1) The Potential of a Mix of Renewable (PV/ Wind) Energy System for an Information and Communication Technology (ICT) Centre in a Rural Environment
}

\author{
Ani Vincent Anayochukwu
}

Department of Electronic Engineering, University of Nigeria, Nsukka, Nigeria. Email: vincent_ani@yahoo.com. Phone Number: +2348054024629

Received 02 March 2013; revision received 02 July 2013; accepted 08 July 2013. Published online 30 December 2013 (www.ejee.cl). DOI 10.7770/ejee-V1N3-art490 . ISSN: 0719269X. @ Renewable Energies Research Nucleus, UC Temuco

ABSTRACT The design is presented of an optimized mix of renewable (PV/Wind) energy system for an Information and Communication Technology (ICT) Center in Rural environments in Kauru (Kaduna State), Northern Nigeria with a daily load of $24 \mathrm{kwh}$ $\mathrm{d}^{-1}$. Solar radiation and wind speed for the design of the system were obtained from the NASA Surface Meteorology and solar energy website at a location of $10^{\circ} 39^{\prime} \mathrm{N}$ latitude and $8^{\circ} 09^{\prime} \mathrm{E}$ longitude, with annual average solar radiation of $5.64 \mathrm{kWh} \mathrm{m}^{-2} \mathrm{~d}^{-1}$ and annual average wind speed of $2.5 \mathrm{~m} \mathrm{~s}^{-1}$. The patterns of load consumption by the ICT Centre were studied and suitably modeled for optimization using the $\mathrm{Na}$ tional Renewable Energy Laboratory's Hybrid Optimization Model for Electric Renewables (HOMER) software. The proposed PV/Wind system was simulated using the model resulting in two different topologies: PV/Wind and PV only. From the simulation results, the PV/Wind system solution was considered to be the best energy option (solution) for the ICT Center. This optimization study indicates that energy requirements to provide electricity for an ICT center in Kauru with the least cost could be accomplished by a combination of $8 \mathrm{~kW} \mathrm{PV}$ array, 1 unit $7.5 \mathrm{~kW}$
BWC Excel-R wind turbine, $1.5 \mathrm{~kW}$ inverter and 24 Hoppecke $24 \mathrm{OPzS} 30000$ batteries. The system configuration suggested also benefits from 33\% excess electricity supply which allows for future ICT network expansion and power needs. This system also saves $\$ 6,341$ for the project lifetime when compared with PV only system due to reduced number of battery unit. A detailed design and description of expected performance of the PV/Wind system are also presented.

KEYwords HOMER, ICT, Remote/Rural Area, Mix of Renewable Energy System, Energy Optimization, Simulation, Nigeria.

\section{Introduction}

Over several decades, rural electrification has been recognized as a powerful tool that increases the living standards in poor and remote communities [Pipattanasomporn, 2004]. Electricity Power supply has been acknowledged as a means of fighting poverty and illiteracy in developing economies like Nigeria, if we are 
to meet the Millennium Development Goals (MDGs) targets [Adejumobi et al., 2011]. In rural communities, Information and Communication Technologies (ICTs) centers have access to a variety of local data, including information about the district, up-to-date market prices of crops and livestock, weather reports and a village newspaper. E-government services are also provided, including access to a host of local government services, such as driving license applications, registration of births and deaths, application for income, caste and domicile certificates, and public complaints. ICT is a tool to facilitate e-service programmes, especially to those institutions such as banks, hospitals and schools in rural and unreached communities and has been expanding rapidly in the past several years in remote villages in Nigeria.

A primary barrier to Internet penetration in rural areas is the lack of the most important element for its functioning, which is electricity. In order for the Internet to be usable and sustained over the long term, reliable local power supply must be provided first. The irony of this situation is that Nigeria is endowed with very abundant renewable energy resources that remained unexplored and unexploited for alternative energy solutions for telecommunications particularly in the largely populated rural areas in the country [Ani and Nzeako, 2012a].

This paper focuses on the renewable energies (Solar-PV and Wind) to generate electricity, and each source is detailed below:

\section{Solar Energy}

Nigeria has an annual average daily sunshine of 6.25 hours, ranging between about 3.5 hours in the coastal areas and 9.0 hours at the far northern boundary [Bala et al., 2000]. Similarly, it has an annual average daily solar radiation of about $5.25 \mathrm{KWh} \mathrm{m}^{-2} \mathrm{~d}^{-1}$, varying between about $3.5 \mathrm{KWh} \mathrm{m}^{-2} \mathrm{~d}^{-1}$ at the coastal area and $7.0 \mathrm{KWh} \mathrm{m}^{-2} \mathrm{~d}^{-1}$ at the northern boundary [Chendo, 2002]. Nigeria lies along the Equator, with abundant sunshine all the year round, receive about $4.851 \times 10^{12} \mathrm{kWh}$ of energy per day from the sun. This is equivalent to about 1.082 million tonnes of oil (mtoe) per day [Ani, 2013b]. This huge energy resou- rce from the sun is available for about $26 \%$ of the day. Based on the land area of $924 \times 10^{3} \mathrm{~km}^{2}$ for the country and an average of $5.535 \mathrm{kWh} \mathrm{m}^{-2} \mathrm{~d}^{-1}$, annually Nigeria has an average of $1.804 \times 10^{15} \mathrm{kWh}$ of incident solar energy [Chendo, 2002].

\section{Wind Energy}

Two principal wind currents affect Nigeria. The southwestern winds dominate the rainy season of the year, while north-eastern winds dominate the dry season. Depending on the shifts in the pressure belts in the Gulf of Guinea, these winds are interspersed respectively by the southeastern and the northwestern winds in different parts of the year [Ani and Nzeako, 2012a]. The wetter winds prevail for more than $70 \%$ of the period due to the strong influence of the Atlantic Ocean. Mean annual wind speed varies between 2 to $6 \mathrm{~m} \mathrm{~s}^{-1}$. Speeds in dry season (November - March) are lower. In the wet season (April-October), daily average speed could rise to $15 \mathrm{~m} \mathrm{~s}^{-1}$. Values of up to 25 $\mathrm{m} \mathrm{s}^{-1}$ are sometimes experienced due to inducement by convective rainfall activities and relative diffusion. From meteorological centres in Nigeria and satellitederived meteorology and solar energy parameters from National Aeronautics and Space Administration (NASA), the average daily wind which spreads across the country, at $50 \mathrm{~m}$ height above the earth, is within the range of $2.7 \mathrm{~m} \mathrm{~s}^{-1}$ in the central western parts to $5.4 \mathrm{~m} \mathrm{~s}^{-1}$ in the North East. Therefore, wind is a great promise for alternative renewable energy for the telecommunications industry in Nigeria [Ani and Nzeako, 2012a].

\section{Review of the Hybrid PV/Wind system}

Solar and wind energy systems are omnipresent, freely available, environmentally friendly, and they are considered as promising power generating sources due to their availability and topological advantages for local power generations. The mix of renewable energy system for this study included the PV generator, wind turbine generator and battery system. Battery storage increases the flexibility of system control and adds to overall system availability [Shaahid and El- 
Hadidy, 2003; Shaahid and El-Hadidy, 2004]. Battery operation in a hybrid system, as opposed to a singlesource application, may result in certain advantages with respect to battery lifetime optimization. This can be attributed to the fact that there is often more sophisticated control installed in a hybrid system due to the interaction of many components. This requires better regulation of components and will result in better treatment of the battery. Moreover, there are more energy sources available resulting in the battery not being utilized as high a degree as in single-source systems. Batteries are costly and can often be sized smaller in a hybrid system than in a single-source system [Ani and Nzeako, 2012b].

These energy systems have good prospects and many opportunities in hot climates. They are termed as one of the cost effective solutions to meet energy requirements of remote areas. The combination of various renewable sources simply makes sense in many scenarios. For instance, when solar and wind power production is used together, the reliability of the system is enhanced. During the same day, in many regions worldwide or in some periods of the year, there are different and opposite patterns in terms of wind and solar resources. These different patterns can make the hybrid systems the best option in electricity production [Ani, 2013a]. For example, a mix of energy sources can accommodate seasonal resource fluctuations, with solar PV collectors complementing wind power during the months with less wind. Where daily energy variations are concerned, solar energy has a production peak around noon, while wind power facilities can operate whenever the wind is blowing. Batteries add stability to the system by storing the energy for peak consumption when there is insufficient production from renewable sources (i.e., to offset lack of solar power during nighttime hours) [Ani, 2013a]. The use of different energy sources allows improving the system efficiency and reliability of the energy supple and reduces the energy storage requirements compared to systems comprising only one single renewable energy source. With the complementary characteristics between solar energy and wind energy for certain locations, the solar-wind power generation systems with storage banks offer a highly reliable source of power [Yang et al., 2007], which is suitable for electrical loads that need higher reliability [Giraud and Salameh, 2001]. A procedure is described in [Markvart, 1996], which determines the sizes of the PV array and wind turbine in a PV/ wind energy system using the measured values of solar and wind energy at a given location. Celik [2002] presented a techno-economic analysis based on solar and wind biased months for autonomous PV/wind energy system. A new technique for the sizing of the PV array and battery storage for a stand-alone windphotovoltaic system has been developed by [Bagul et al., 1996]. These authors observed that an optimum combination of the PV/wind energy system provides higher system performance than a single system, for the same system cost and battery storage capacity.

In tropical regions like Nigeria, PV and Wind are a good match, because wind speeds are lower in dry seasons when the sun is high and higher in the rainy season when the sunshine is rather low [Ani and Nzeako, 2012b].

The aim of this paper,,therefore, is to: (i) design an optimized PV/Wind energy system that will produce the desired power needs and show the potential of renewable energy in powering ICT Centers in Nigeria, (ii) to compare the optimized PV/Wind energy system with an optimized PV only system in terms of cost analysis and electricity generated. A detailed design and description of expected performance of the $\mathrm{PV} /$ Wind system are presented in this paper.

\section{Energy Consumptions}

The ICT load profile depends on multiple parameters such as the Router, Port fast Switch, Wireless Access Point, Server (plus accessories), RF (Radio Communication), Laptops (with security cables), VOIP Phones, Laser Printer, Lighting and Ceiling fans. Therefore it is important to outline an accurate power profile in order to dimension correctly the alternative energy components for the system. The only way to "outline an accurate power profile" is to answer the question: what are the times when the loads are used, and this 
Table 1 Energy needed for a typical ICT Center in Rural environments.

\begin{tabular}{|lcccc|}
\hline Description of Item & Qty & Load (Watts per unit) & $\begin{array}{c}\text { Total Load } \\
\text { (Watts) }\end{array}$ & $\begin{array}{c}\text { Daily Hour of actual } \\
\text { Utilization (h) }\end{array}$ \\
\hline Router & 1 & 25 & 25 & 24 \\
\hline Port fast Switch & 1 & 15 & 15 & 24 \\
\hline Wireless Access Point & 2 & 12 & 24 & 24 \\
\hline Server (plus accessories) & 1 & 150 & 150 & 24 \\
\hline RF (Radio Communication) & 1 & 40 & 40 & 24 \\
\hline Laptops (with security cables) & 10 & 40 & 400 & 8 \\
\hline VOIP Phones & 2 & 20 & 40 & 4 \\
\hline Laser Printer & 1 & 100 & 100 & 24 \\
\hline Lighting & 4 & 15 & 60 & 240 \\
\hline Ceiling fans & 4 & 60 & & 24 \\
\hline
\end{tabular}

will give us a baseline data on energy consumptions. From the acquired data, a profile of the ICT center was created and shown in Tables 1 and 2.

The daily average load variation is shown in Fig. 1 and Table 2; it is assumed that it is identical for every day of the year. The annual peak load of $1.1 \mathrm{~kW}$ was observed between 9:00 $\mathrm{h}$ and 13:00 $\mathrm{h}$, with $24 \mathrm{kWh}$ $\mathrm{d}^{-1}$ energy consumption.

\section{Simulation and Optimization Software}

The Hybrid Optimization Model for Electric Renewables (HOMER) is a computer model that simpli-

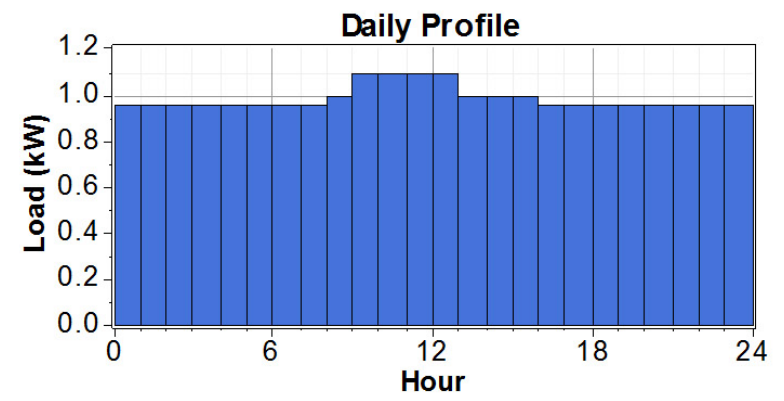

Figure 1 Daily average load variation for a typical ICT Center in Rural environments. fies the task of evaluating design options for both offgrid and grid-connected power systems for remote, stand-alone and distributed generation (DG) applications [NREL, 2005]. It has been developed by The National Renewable Energy Laboratory (NREL), United States (US) since 1993. It was developed specifically to meet the needs of the renewable energy industry system analysis and optimization [Lau et al., 2010].

The simulation process serves two purposes. First, it determines whether the system is feasible. HOMER considers the system to be feasible if it can adequately serve the electric and thermal loads and satisfies any other constraints imposed by the user. Second, it estimates the life-cycle cost of the system, which is the total cost of installing and operating the system over its lifetime. In the optimization process, HOMER performs simulation on different system configurations to come out with the optimal selection. In the sensitivity analysis process, HOMER performs multiple optimizations under a range of inputs to account for uncertainty in the model inputs. 
Table 2 The electrical load (Daily load demands) data for a typical ICT Center in Rural Environments.

\begin{tabular}{|c|c|c|c|c|c|c|c|c|c|c|c|}
\hline $\begin{array}{l}\text { Time } \\
\text { (Hr) }\end{array}$ & $\begin{array}{c}\text { Router } \\
\text { (W) }\end{array}$ & $\begin{array}{l}\text { Port fast } \\
\text { Switch } \\
\text { (W) }\end{array}$ & $\begin{array}{l}\text { Wireless } \\
\text { Access } \\
\text { Point (W) }\end{array}$ & $\begin{array}{c}\text { Server } \\
\text { (W) }\end{array}$ & $\begin{array}{l}\text { RF } \\
\text { (W) }\end{array}$ & $\begin{array}{l}\text { Laptops } \\
\text { (W) }\end{array}$ & $\begin{array}{l}\text { VOIP } \\
\text { Phones } \\
\text { (W) }\end{array}$ & $\begin{array}{l}\text { Laser } \\
\text { Printer } \\
\text { (W) }\end{array}$ & $\begin{array}{l}\text { Lighting } \\
\text { (W) }\end{array}$ & $\begin{array}{l}\text { Ceiling } \\
\text { fans } \\
\text { (W) }\end{array}$ & $\begin{array}{l}\text { Total } \\
\left(\mathrm{W} \mathrm{h}^{-1}\right)\end{array}$ \\
\hline 00-01 & 25 & 15 & 24 & 150 & 40 & 400 & & & 60 & 240 & 954 \\
\hline 01-02 & 25 & 15 & 24 & 150 & 40 & 400 & & & 60 & 240 & 954 \\
\hline $02-03$ & 25 & 15 & 24 & 150 & 40 & 400 & & & 60 & 240 & 954 \\
\hline 03-04 & 25 & 15 & 24 & 150 & 40 & 400 & & & 60 & 240 & 954 \\
\hline 04-05 & 25 & 15 & 24 & 150 & 40 & 400 & & & 60 & 240 & 954 \\
\hline 05-06 & 25 & 15 & 24 & 150 & 40 & 400 & & & 60 & 240 & 954 \\
\hline $06-07$ & 25 & 15 & 24 & 150 & 40 & 400 & & & 60 & 240 & 954 \\
\hline 07-08 & 25 & 15 & 24 & 150 & 40 & 400 & & & 60 & 240 & 954 \\
\hline 08-09 & 25 & 15 & 24 & 150 & 40 & 400 & & & 60 & 240 & 954 \\
\hline $09-10$ & 25 & 15 & 24 & 150 & 40 & 400 & 40 & & 60 & 240 & 994 \\
\hline $10-11$ & 25 & 15 & 24 & 150 & 40 & 400 & 40 & 100 & 60 & 240 & 1094 \\
\hline $11-12$ & 25 & 15 & 24 & 150 & 40 & 400 & 40 & 100 & 60 & 240 & 1094 \\
\hline $12-13$ & 25 & 15 & 24 & 150 & 40 & 400 & 40 & 100 & 60 & 240 & 1094 \\
\hline $13-14$ & 25 & 15 & 24 & 150 & 40 & 400 & 40 & 100 & 60 & 240 & 1094 \\
\hline $14-15$ & 25 & 15 & 24 & 150 & 40 & 400 & 40 & & 60 & 240 & 994 \\
\hline $15-16$ & 25 & 15 & 24 & 150 & 40 & 400 & 40 & & 60 & 240 & 994 \\
\hline $16-17$ & 25 & 15 & 24 & 150 & 40 & 400 & 40 & & 60 & 240 & 994 \\
\hline $17-18$ & 25 & 15 & 24 & 150 & 40 & 400 & & & 60 & 240 & 954 \\
\hline $18-19$ & 25 & 15 & 24 & 150 & 40 & 400 & & & 60 & 240 & 954 \\
\hline $19-20$ & 25 & 15 & 24 & 150 & 40 & 400 & & & 60 & 240 & 954 \\
\hline $20-21$ & 25 & 15 & 24 & 150 & 40 & 400 & & & 60 & 240 & 954 \\
\hline $21-22$ & 25 & 15 & 24 & 150 & 40 & 400 & & & 60 & 240 & 954 \\
\hline $22-23$ & 25 & 15 & 24 & 150 & 40 & 400 & & & 60 & 240 & 954 \\
\hline $23-00$ & 25 & 15 & 24 & 150 & 40 & 400 & & & 60 & 240 & 954 \\
\hline Total & 600 & 360 & 576 & 3600 & 960 & 9600 & 320 & 400 & 1440 & 5760 & 23616 \\
\hline
\end{tabular}




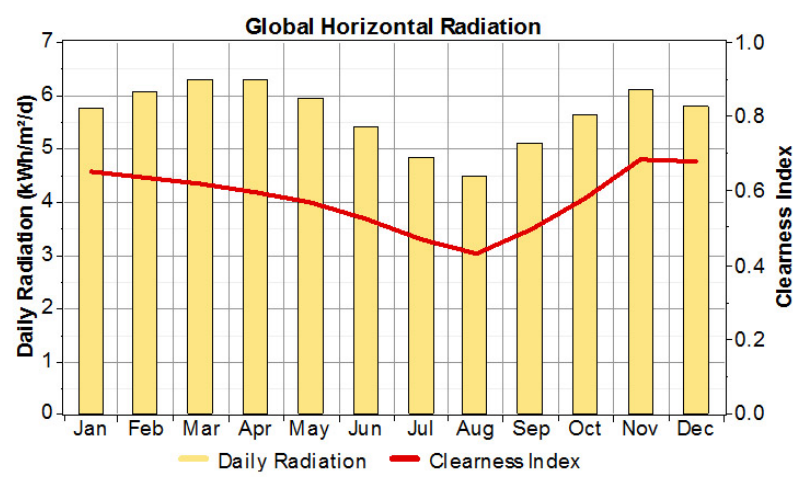

Figure 2a Average Solar (clearness index and radiation) profile for Kauru (Kaduna State).

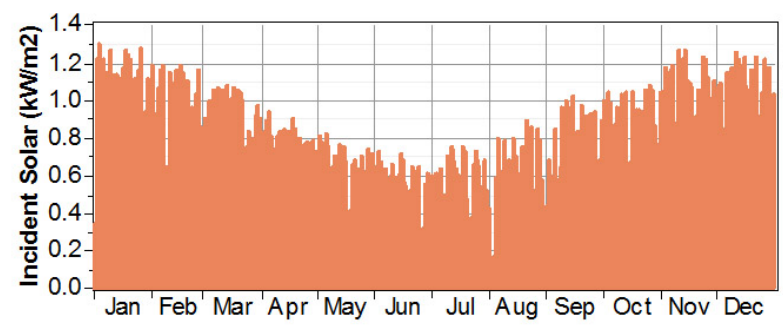

Figure 2b Daily Incident Solar for Kauru (Kaduna State).

\section{Study area}

The study area was kauru (Kaduna State) at a specific geographical location of $10^{\circ} 39^{\prime} \mathrm{N}$ latitude and $8^{\circ} 09^{\prime} \mathrm{E}$ longitude with annual average solar (clearness index and radiation) of $5.64 \mathrm{kWh} \mathrm{m}^{-2} \mathrm{~d}^{-1}$ and wind speed of $2.5 \mathrm{~m} \mathrm{~s}^{-1}$. The data for solar and wind resources were obtained from the NASA Surface Meteorology and Solar Energy web site [NASA, 2012]. For this study, solar PV and wind technology were considered. Figs. $2 \mathrm{a}, 2 \mathrm{~b}, 3 \mathrm{a}$ and $3 \mathrm{c}$ show the solar and wind resource profile for the location shown in Table 3.

In solar resource, March is the sunniest month of the year. During this month (March), the solar energy resource is $6.32 \mathrm{kWh} \mathrm{m}^{-2} \mathrm{~d}^{-1}$ while in August it is only $4.47 \mathrm{kWh} \mathrm{m}^{-2} \mathrm{~d}^{-1}$ as shown in Fig. 2 ( $\mathrm{a}$ and $\mathrm{b}$ ) and Table 3. Whereas in wind resource, September is the least windy month of the year while March, April and May are the windiest. Expected maximum wind speed is $2.8 \mathrm{~ms}^{-1}$ as shown in Fig. 3 (a and b) and Table 3 .

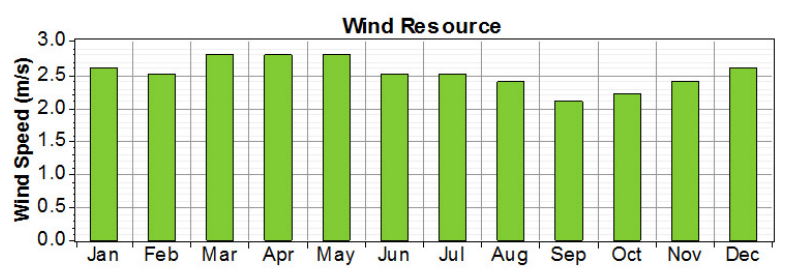

Figure 3a Average Wind Speed profile for Kauru (Kaduna State).

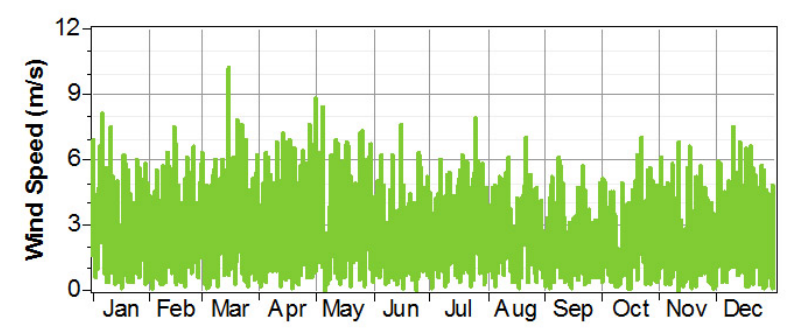

Figure 3b Daily Wind Speed for Kauru (Kaduna State)

\section{Model Development}

The following equations are based on the equations used by (Ani, in press; HOMER, 2012; Kamaruzzaman et al, 2008; Lambert, 2009) to derive the power supplied by renewable, battery charging and discharging.

\section{PV Power:}

$$
P_{P V}=\eta_{P V} \cdot N_{P V P} \cdot N_{P V S} \cdot V_{P V} \cdot I_{P V}
$$

Wind Power:

$$
P_{W T}=\eta_{W T} \cdot \eta_{g} \cdot 0.5 \cdot \rho_{a} \cdot C_{P} \cdot A \cdot V_{r}^{3}
$$

Total Renewable Power:

$$
P(t)=\sum_{P V=1}^{n_{P V}} P_{P V}+\sum_{W T=1}^{n_{W T}} P_{W T}
$$

Battery Discharging:

$$
P_{B}(t)=P_{B}(t-1) \cdot(1-\sigma)-\left[\frac{P_{B R}(t)}{P_{B L}(t)}\right]
$$


Table 3 Wind and Solar Resources for Kauru - Kaduna State.

\begin{tabular}{|lccc|}
\hline Month & $\begin{array}{c}\text { Clearness Index } \\
\left(\mathrm{kWh} \mathrm{m}^{-2} \mathrm{~d}^{-1}\right)\end{array}$ & $\begin{array}{c}\text { Average solar Radiation } \\
\left(\mathrm{kWh} \mathrm{m}^{-2} \mathrm{~d}^{-1}\right)\end{array}$ & $\begin{array}{c}\text { Average Wind Speed } \\
\left(\mathrm{m} \mathrm{s}^{-1}\right)\end{array}$ \\
\hline Jan & 0.654 & 5.760 & 2.600 \\
Feb & 0.638 & 6.060 & 2.500 \\
\hline Mar & 0.620 & 6.320 & 2.800 \\
\hline Apr & 0.598 & 6.300 & 2.800 \\
May & 0.568 & 5.940 & 2.800 \\
Jun & 0.523 & 5.400 & 2.500 \\
\hline Jul & 0.469 & 4.850 & 2.500 \\
\hline Aug & 0.428 & 4.470 & 2.400 \\
Sep & 0.498 & 5.110 & 2.100 \\
Oct & 0.583 & 5.630 & 2.200 \\
Nov & 0.684 & 6.110 & 2.400 \\
\hline Dec & 0.678 & 5.790 & 2.600 \\
\hline Scaled annual average & & 5.641 & 2.518 \\
\hline
\end{tabular}

Battery Charging:

$$
P_{B}(t)=P_{B}(t-1) \cdot(1-\sigma)+\left\lfloor P_{B R}(t)-P_{B L}(t)\right] \cdot \eta_{B B}
$$

Where,

$V_{P V} \quad$ : Operating voltage of PV panels

$N_{P V S} \quad$ : Numbers of PV panels in series

$\eta_{g} \quad$ : Efficiency of the gravitational acceleration

$P_{W T} \quad$ : Wind turbine power output

$\eta_{W T} \quad:$ Efficiency of wind turbine

$\rho_{a} \quad$ : Density of air

$C_{P} \quad$ : Power coefficient of wind turbine

$A \quad$ : Wind turbine swept area

$V_{r}^{3} \quad$ : Wind velocity

$P_{P V} \quad:$ PV power output

$\eta_{P V} \quad$ : Conversion efficiency of $\mathrm{PV}$

$N_{P V P}:$ Number of PV panels in parallel

$N_{P V S} \quad$ : Number of PV panels in series

$I_{P V} \quad$ : Operating current of PV panels
$P_{B} \quad$ : Battery energy at time interval

$P_{B R} \quad$ : Total energy generated

$\sigma \quad:$ Self discharge factor

$P_{B L} \quad$ : Load demand at time interval

$\eta_{B B} \quad$ : Battery charging efficiency

During the optimization procedure, the sizes of system components are decision variables.

\section{Power Design}

In order to design a power system for the ICT Center, it was necessary to obtain information about the particular location of the ICT Center, such as the resources available and the load profile that should be met by the system [Ani, 2013b]. The proposed mix of renewable energy system consists of a wind turbine and solar photovoltaic (PV) panels with batteries added as part of a backup and storage system. The proposed system is shown in Fig. 4. 


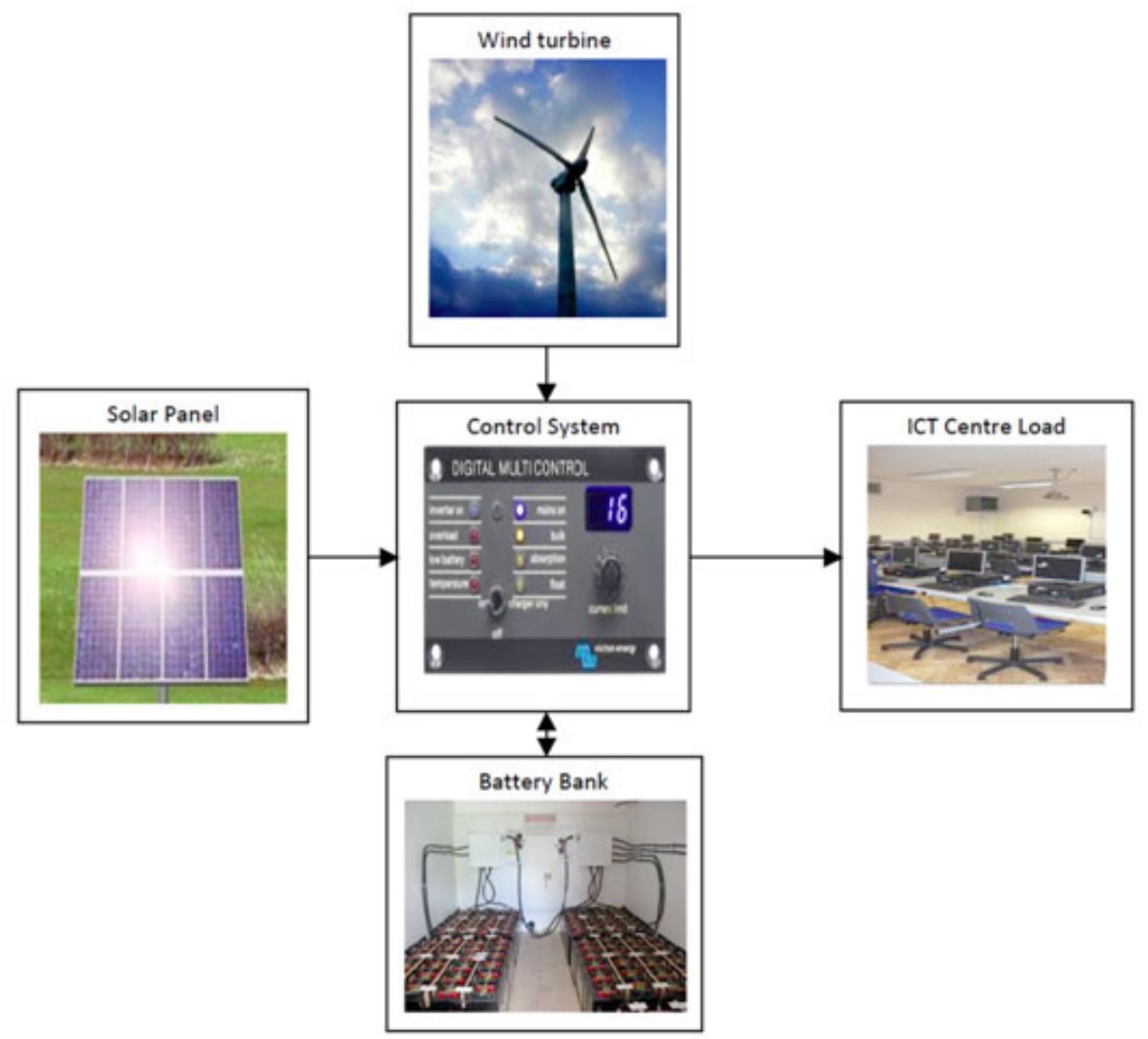

Figure 4 Architecture of the Proposed Stand-alone Hybrid System.

Mix of Renewable Energy System

Components

\section{Photovoltaic Module}

The PV module has a derating factor of $80 \%$. No tracking system is incorporated as part of the PV system design. The cost of PV module has been given in Table 4 .

\section{Wind turbine model}

The number of BWC Excel-R 7.5 kW DC wind turbines considered for the simulation was one. The cost of the wind turbine has been given in Table 4 .

\section{Storage Battery}

The variations of solar and wind energy generation do not match the time distribution of the demand. The storage battery chosen was Hoppecke $24 \mathrm{OPzS}$ 30000. From the datasheet given by the HOMER software, the minimum state of charge of the battery is
$30 \%$. Its round trip efficiency is $86 \%$ [Battery Experts, 2012]. Batteries are considered as a major cost factor in small-scale stand-alone power systems.

\section{Inverter}

In the present case, the size of the inverter was $1.5 \mathrm{~kW}$ for simulation purposes. The inverter had an efficiency of $85 \%$.

\section{Constraints}

Operating reserve is the safety margin that helps ensure reliability of the supply despite variability in electric load, solar power supply and the wind power supply. The operating reserve as a percentage of hourly load was $10 \%$. Meanwhile, the operating reserve as a percentage of solar power output and wind power output was $25 \%$ and $50 \%$ respectively. 


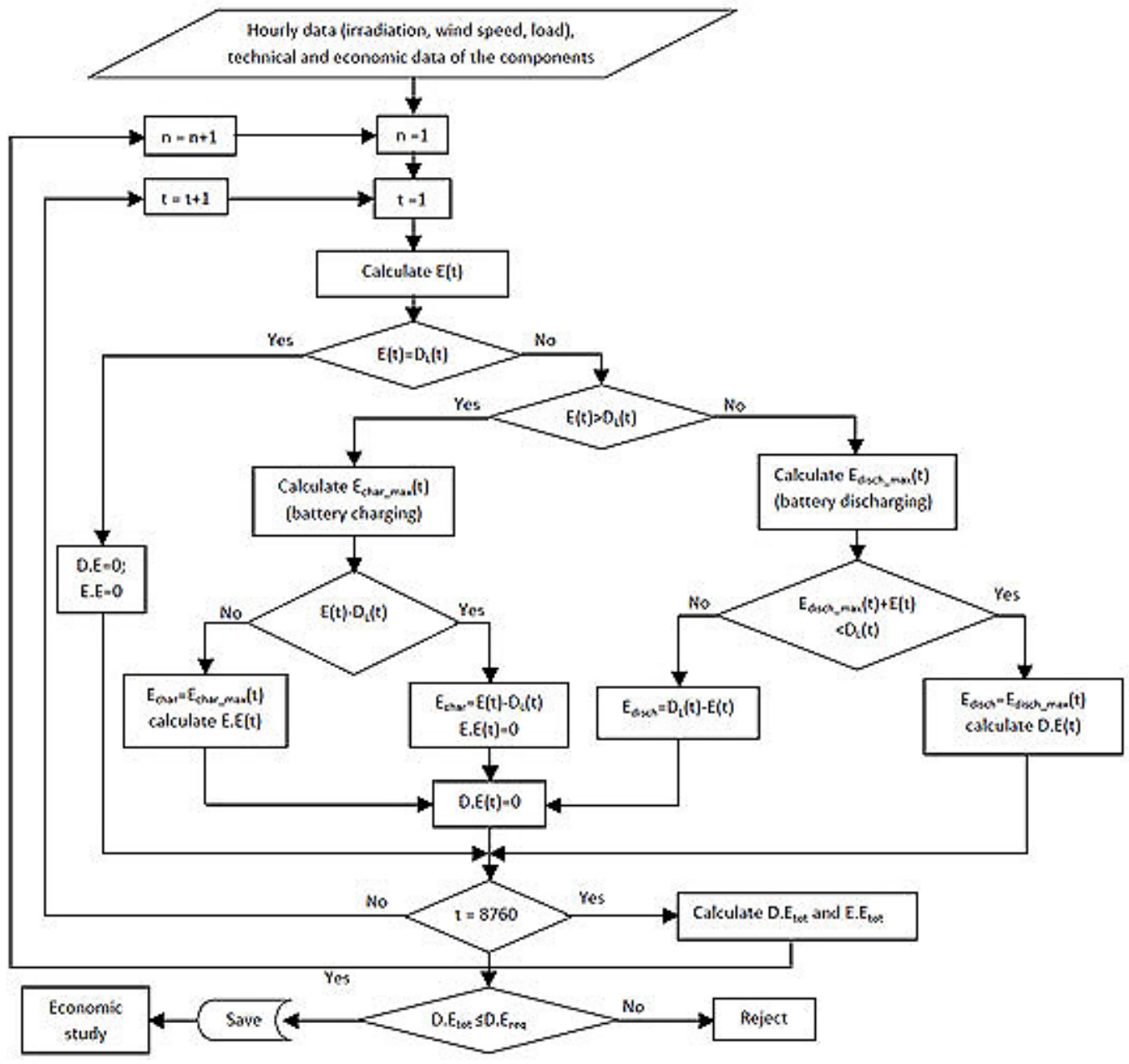

Figure 5 Optimization Chart of the hybrid PV-Wind system.

\section{Control Strategies}

The configuration of the stand-alone PV/Wind system is shown in Fig. 7. In the proposed PV/Wind energy system with batteries, the dispatch strategy was as follows: the battery charges if the mix of renewable energy is in excess after meeting the demand, and the battery discharges if the load exceeds the mix of renewable energy system.

The input parameters and system constraints as described above, were used to simulate hybrid systems and perform the optimization analysis.

\section{Optimization Algorithm}

The optimization algorithm of the hybrid system of renewable energy used by the HOMER Software in simulation is presented in Fig. 5. Inputs of the algorithm are the technical and economic data of all the components of the system [Souissi et al., 2010]. These data cover the climatic variation, the load and the constraints on the operation of the system. The inputs to the simulator (HOMER) are mentioned previously. For each combination $\mathrm{n}$, the total power, $\mathrm{E}(\mathrm{t})$, generated by the PV generator and wind turbine at the hour $\mathrm{t}$ is calculated as follows:

$$
\mathrm{E}(\mathrm{t})=\mathrm{E}_{\mathrm{PV}}(\mathrm{t})+\mathrm{E}_{\mathrm{WT}}(\mathrm{t})
$$

During system operation of the PV/Wind system, different situations may appear:

The total energy generated by the PV and Wind generators can be greater than the load demand $\left(D_{L}(t)\right)$. In this situation, the energy surplus is stored in the 
batteries $\left(\mathrm{E}_{\mathrm{char}}\right)$ after calculation, as a preliminary, the maximum amount of energy that can be charged $\left(E_{\text {char_max }}(t)\right)$ in the battery bank. The excess of energy (E.E(t)), if it exists, is calculated for each hour.

The demand of the load can be greater than the total energy generated by the PV and Wind generators. In this case, the load must be covered by the energy stored in batteries $\left(\mathrm{E}_{\mathrm{disch}}\right)$ after calculating, as a preliminary, the maximum amount of energy that can be discharged $\left(E_{\text {disch_max }}(t)\right)$ from the battery bank. The deficit of energy (D.E(t)), if there exists, is calculated for each hour.

The load demand can be equal to the total energy generated by the PV and Wind generator, the battery's capacity remains unchanged.

The total excess (E. $E_{\text {tot }}$ ) and deficit (D.E $\left.E_{\text {tot }}\right)$ of energy that can occur during the year are calculated to decide the rejection or the save of the combination, by comparison between the total deficit and that required (D.E $\mathrm{E}_{\mathrm{req}}$ ).

Finally, an economic study is done allowing a classification of the feasible combinations according to the total net present cost of the system.

\section{Controller and Simulation for Validating Optimization Results}

The method of validating the optimization algorithm result is using a virtual controller and simulating the control of the system over the year period and monitoring the times of loss of supply, and the power supplied by the PV panels, wind turbines and battery in relation to the power required by the load.

A sliding control was used for this, using the PV energy generation as the primary source of energy, wind energy generation as the secondary source and battery as the supplement and backup. The system move between different mode depending on the power needed by the load and the power able to be supplied by each of the sources. Fig. 6 outlines the flow between the different modes.

Initially, the power supplied by the PV panels and the wind turbines is calculated for each hour over the year and stored in matrices, so that power availabi- lity in each hour can be accessed easily. The control process then begins at hour 1 . The first decision loop looks at the power that can be supplied by the PV panel in this hour and the power required by the load. If the power generated by the PV panel is sufficient to match the load, the system enters Mode 1. If the PV panel cannot provide sufficient energy to the load, the control looks at the total amount of energy that can be provided by the PV panel and the wind turbine together. If these together are sufficient to provide power to the load, the system enters Mode 2. If the combined energy supplied by the PV panels and the wind turbine is not sufficient to supply the load, the state of charge of the battery is considered. If the battery SOC is not at its minimum value, the system enters Mode 3. The detailed mode of operational control (sliding) is given below:

\section{Mode 1}

Mode 1 uses solely the energy generated by the PV panel to supply the load. When the system is in mode 1 , at times, the energy available from the PV panel might be in excess of what is needed by the load and therefore the amount of energy supplied to the load must be matched to the load demand. This is called sliding control. As the wind turbines are connected to the system, but not used to supply the load in this mode, the energy generated by the wind turbine as well as any excess energy from the PV panels can be used to charge the battery.

During the charging of the battery, if the SOC of the battery is at its maximum possible SOC value, the excess power is sent to a dump load [Dump load is a device to which power flows when the system batteries are too full to accept more power], which can be defined according to the ICT's needs, charging of phones, etc. The flowchart inside the dotted line shown in Fig. 6 is the charging control circuit. If the SOC of the battery is less than the maximum SOC, the amount of excess power is checked. Battery-Experts [2012] advised not to use a charging current of more than $60 \mathrm{~A}$. The power is then checked to make sure that the current used to charge the battery will 


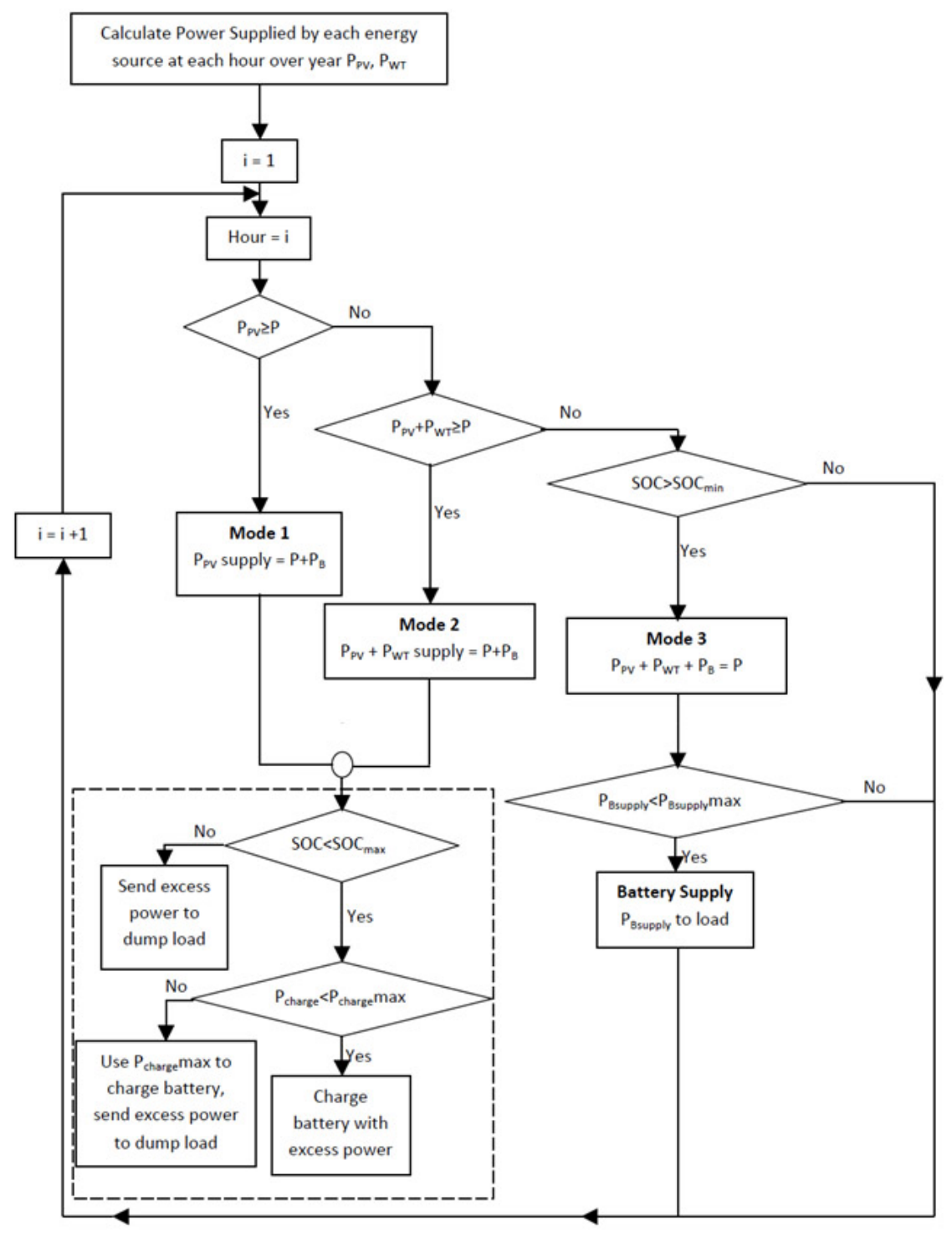

Figure 6 Flowchart of modes of control for Hybrid PV/Wind Energy System.

be less than 60A. If the excess power is less than this maximum charging power, the battery is charged with the full excess power. If the power is above that of maximum charging of the battery, the maximum battery charge power is used to charge the battery and the excess is used for the dump load.

\section{Mode 2}

Mode 2 uses the power of the PV panels plus the power of the wind turbine to supply the load. In Mode 2 , if the energy available from the PV panel and the wind turbine combined is in excess of what is needed by the load, then the full power available from the PV panels is used to supply the load and the power from the wind turbine is supplied using the sliding control to match the power required by the load. The excess energy from the PV panels and the wind turbine can be used to charge the battery, as in Mode 1.

\section{Mode 3}

The system enters Mode 3 when the power generated by the PV panels and wind turbine is not sufficient to supply the load, but the SOC of the battery is greater than the minimum amount and therefore the 
Table 4 Summary of initial system costs, Replacement costs and Operating \& Maintenance costs

\begin{tabular}{|c|c|c|c|}
\hline Item & Initial system costs & Replacement costs & $\begin{array}{l}\text { Operating \& maintenance } \\
\text { costs }\end{array}$ \\
\hline PV Modules & \# 324/W (\$2) & \# 291.6/W (\$1.8) & A 16,200/kW/yr (\$100) \\
\hline $\begin{array}{l}\text { BWC Excel-R7.5kW Wind } \\
\text { Turbine }\end{array}$ & A2,916,000 $(\$ 18,000)$ & \#2,430,000 $(\$ 15,000)$ & * 16,200 (\$100) \\
\hline $\begin{array}{l}\text { Hoppecke } 24 \text { OPzS } 30000 \\
\text { Battery }\end{array}$ & A $185,490(\$ 1,145)$ & \# 162,000 (\$1,000) & A 16,200 (\$100) \\
\hline Inverter & \# 324/W (\$2) & \# 324/W (\$2) & \# 0/kW/yr (\$0) \\
\hline
\end{tabular}

battery is able to supply power to the load. The full power generated by the PV panels and wind turbine is supplied to the load. There is however a possibility that the amount of power required by the load is not able to be supplied by the battery. Manufacturers specify that the batteries should not supply more than $80 \mathrm{~A}$ current, and therefore the amount of power needed to be supplied by the batteries must be checked before it can supply that amount. If the load power needed to be supplied by the batteries is below this maximum, the battery then supplies the load power. Otherwise, load cannot be supplied.

From this control simulation, the performance of the system is seen over the course of the year as well as which modes the system spends most time in, the power supplied by each of the energy sources and the power required by the load. This is useful to check how the system is being supplied and which source of energy is the most proficient in supplying the load.

\section{System Economics}

The capital costs of all system components including PV module, wind turbine, inverter, battery and balance of system prices are based on quotes from PV system suppliers in Nigeria [Solarshopnigeria, 2012]. They are likely to vary from the actual system quotes due to many market factors, and are therefore only indicative. The replacement costs of equipment are estimated to be $20 \%-30 \%$ lower than the initial costs, but because decommissioning and installation costs need to be added, it was assumed that they are the same as the initial costs.

The PV array, wind turbine, Inverter and battery maintenance costs are estimates based on approximate time required and estimated wages for this work in a remote area of Nigeria. All initial costs including installation and commissioning, replacement costs and operating \& maintenance costs are summarized in Table 4.

As HOMER calculates in US Dollar (\$), all costs have been converted from Naira ( $\mathrm{N}$ ) into USD (\$) as shown in Table 4 using the equivalent as 1 US Dollar (\$) equal to $\$ 162$ of Nigerian currency (Exchange rate, accessed on $07 / 17 / 2012$ ).

\section{Configuration of Solar-Wind System Components}

The design of a stand-alone PV/Wind system is site specific and depends on both the resources available and the load demand [Ani, 2012b]. A typical standalone solar/wind system consists of the PV array, wind turbine, battery bank, inverter, and other accessory devices and cables. The proposed energy system for the ICT Center consists of PV/Wind power as depicted in Fig. 7. The PV array and wind turbine work together to satisfy the load demand. When the energy sources (solar and wind energy) are abundant, the generated power, after satisfying the load demand, will be supplied to feed the battery until it's fully charged. On the contrary, when energy sources are poor, the 


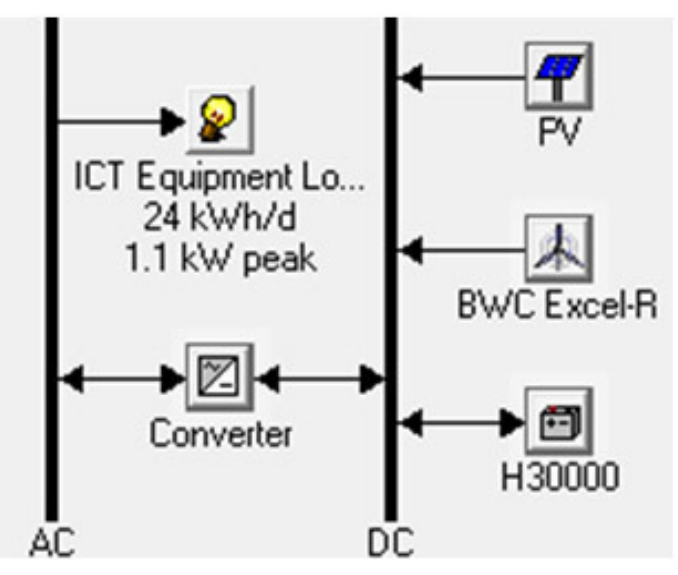

Figure 7 Network Architecture of the Proposed Stand-Alone Hybrid PV/Wind System.

battery will release energy to assist the PV array and wind turbine to cover the load requirements until the storage is depleted.

\section{Simulation of the PV/wind hybrid schemes}

The combined schemes were analyzed using simulation software called HOMER to predict the feasibility of the energy schemes in terms of the system's capital cost, replacement, operation and maintenance, as well as annual electricity energy production study. It simulated the system operation by making energy balance calculations for each of the $8760 \mathrm{~h}$ in a year. Further details are given in [Lambert et al., 2006]. For the simulation of the ICT center, the system components considered were PV arrays, wind turbine and battery. The inverter converts the direct current (DC) power produced to alternate current (AC) power which can conveniently power all electrical appliances that are being used at the ICT Center such as laptops, a laser printer, lighting, etc. The lifetime of the project was estimated at 20 years with a fixed annual interest rate of $6 \%$. The simulation was performed with the assumption that the daily operation hour for the system was constant. The proposed renewable Hybrid PV/ Wind system was simulated using the model which resulted in two different topologies:

The Hybrid PV/Wind system had the following system design: $8 \mathrm{~kW}$ PV array, 1 unit $7.5 \mathrm{~kW}$ BWC

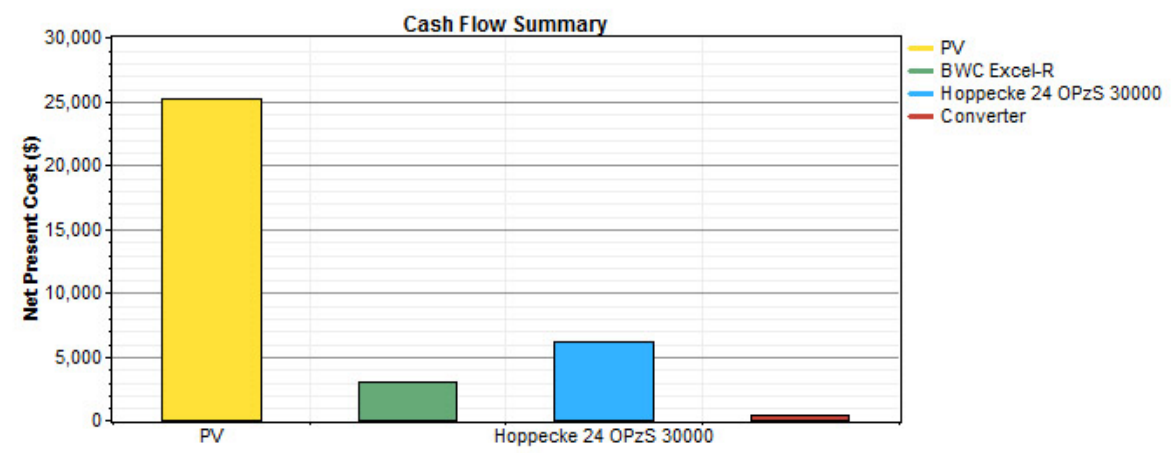

Figure 8 Net Present Cost of component of optimized PV/Wind hybrid system for ICT Center.

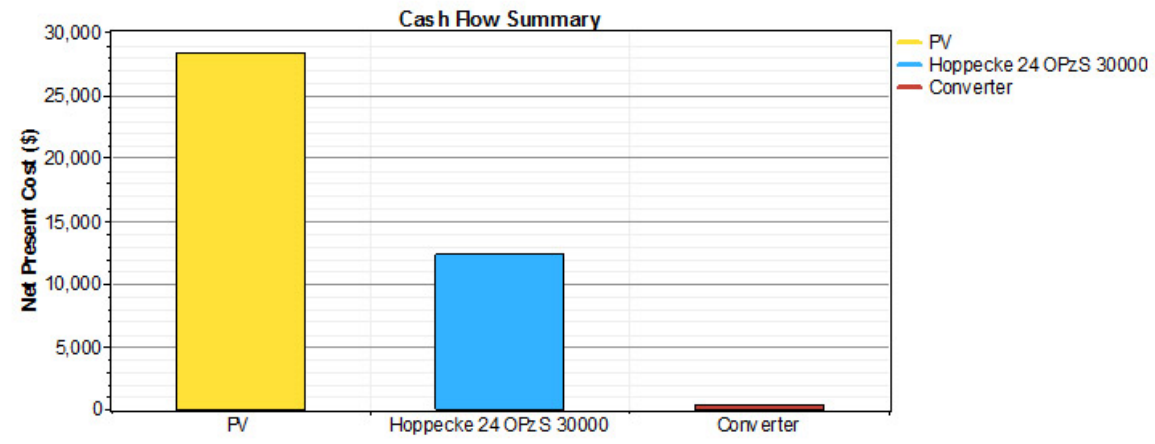

Figure 9 Net Present Cost of component of PV system for ICT Center. 
Table 5 Cash Summary of Energy Components for ICT Center.

\begin{tabular}{|lcccccc|}
\hline & \multicolumn{2}{c}{ Capital Cost(\$) } & \multicolumn{2}{c|}{ O\&M Cost(\$) } & \multicolumn{2}{c|}{ Total NPC(\$) } \\
Component/Costs & $\begin{array}{c}\text { PV/Wind- } \\
\text { Battery } \\
\text { System }\end{array}$ & $\begin{array}{c}\text { PV-Battery } \\
\text { System }\end{array}$ & $\begin{array}{c}\text { PV/Wind- } \\
\text { Battery } \\
\text { System }\end{array}$ & $\begin{array}{c}\text { PV-Battery } \\
\text { System }\end{array}$ & $\begin{array}{c}\text { PV/Wind- } \\
\text { Battery } \\
\text { System }\end{array}$ & $\begin{array}{c}\text { PV-Battery } \\
\text { System }\end{array}$ \\
PV & 16,000 & 18,000 & 9,176 & 10,323 & 25,176 & 28,323 \\
BWC Excel-R & 1,800 & & 1,147 & & 2,947 & \\
Hoppecke 24 OPzS 30000 & 5,040 & 10,080 & 1,101 & 2,202 & 6,141 & 12,282 \\
Inverter & 420 & 420 & 0 & 0 & 420 & 420 \\
System & 23,260 & 28,500 & 11,424 & 12,525 & 34,684 & 41,025 \\
\hline
\end{tabular}

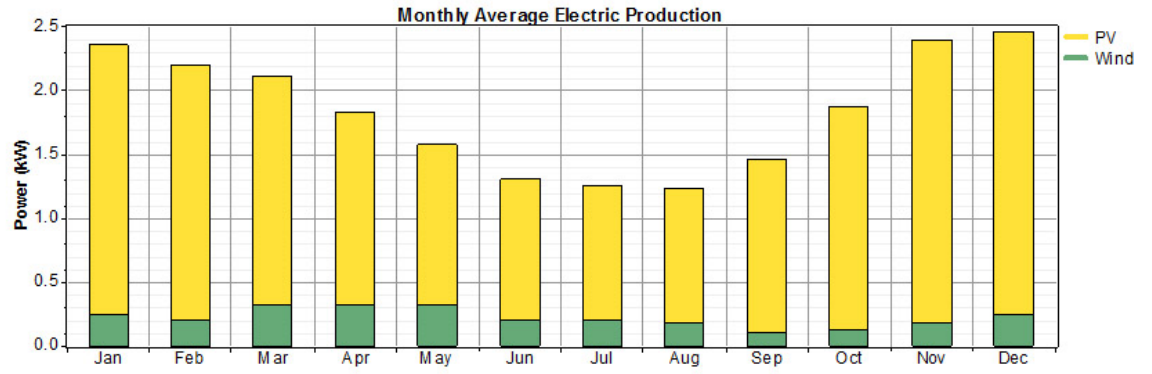

Figure 10 Electric production of PV/Wind hybrid system.

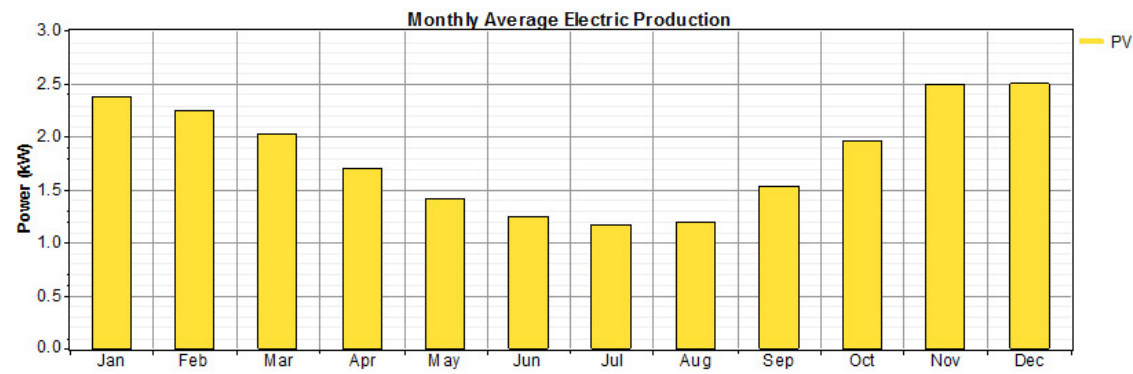

Figure 11 Electric production of PV only system.

Excel-R wind turbine, $1.5 \mathrm{~kW}$ inverter and 24 units Hoppecke $24 \mathrm{OPzS} 30000$ batteries.

The PV only system had the following system design: $9 \mathrm{~kW}$ PV array, $1.5 \mathrm{~kW}$ inverter and 48 units Hoppecke $24 \mathrm{OPzS} 30000$ batteries. These two different system designs were compared in terms of cost analysis and electricity generated.

\section{Results and discussion}

Cost analysis for the simulated hybrid PV/ Wind scheme

The costs of the systems were estimated and analyzed by employing the HOMER simulation and the results obtained (Fig. 8 and 9) are summarized in Table 5. The cost analysis includes the initial cost, operation and maintenance (O\&M) cost and the total Net Present Cost. The system's lifetime of 20 years was taken into consideration. The rate of interest or share char- 
Table 6 Electricity Production, losses and Consumption of the ICT Center.

\begin{tabular}{|c|c|c|c|c|}
\hline \multirow{2}{*}{ Electricity } & \multicolumn{2}{|c|}{ PV/Wind system } & \multicolumn{2}{|c|}{ PV system } \\
\hline & $k W h y^{-1}$ & $\%$ & kWh $\mathrm{yr}^{-1}$ & $\%$ \\
\hline \multicolumn{5}{|l|}{ Production } \\
\hline PV array & 14,196 & 88 & 15,970 & 100 \\
\hline Wind turbine & 1,906 & 12 & & \\
\hline Total & 16,102 & 100 & 15,970 & 100 \\
\hline \multicolumn{5}{|l|}{ Losses } \\
\hline Inverter & 1,520 & & 1,520 & \\
\hline Battery & 717 & & 811 & \\
\hline Total & 2,237 & & 2,331 & \\
\hline \multicolumn{5}{|l|}{ Consumption } \\
\hline AC load & 8,613 & 100 & 8,613 & 100 \\
\hline Total & 8,613 & 100 & 8,613 & 100 \\
\hline Excess Electricity & 5,252 & 33 & 5,026 & 31 \\
\hline
\end{tabular}

ges were assumed 6\% and the Total Net Present Cost of PV/Wind Hybrid system and PV only system were $\$ 34,684$ and $\$ 41,025$, respectively, with a difference of $\$ 6,341$.

The simulated hybrid PV/Wind scheme analysis

The simulated results obtained from HOMER showed that in the PV/Wind Hybrid system, the PV arrays contributed most of the energy for the whole year

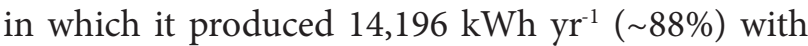
a capacity factor of $20.3 \%$ followed by wind power that produced $1,906 \mathrm{kWh} \mathrm{yr}^{-1}(\sim 12 \%)$ with a capacity factor of $2.90 \%$ which gives a total of $16,102 \mathrm{kWh}$ $\mathrm{yr}^{-1}(100 \%)$ as shown in Table 6. In September, the wind electricity scheme was merely able to contribute minimum power, this is because unlike other periods there is no significant breese during this period as can be clearly seen in Fig. 10; whereas in PV only system, the PV arrays generate $15,970 \mathrm{kWh} \mathrm{yr}^{-1}(100 \%)$ alone with a capacity factor of $20.3 \%$ as shown in Table 6. In July, the solar electricity has the least minimum power generated; this is because unlike other periods there is always rainfall during this period as can be clearly seen in Fig. 11.

The total load of the ICT Center [(mainly consists of Router, Port fast Switch, Wireless Access Point, Server (plus accessories), RF (Radio Communication), Laptops (with security cables), VOIP Phones, Laser Printer, Lighting and Ceiling fans)] corresponding to a total AC primary load of $8,613 \mathrm{kWh} \mathrm{yr}^{-1}$.

Therefore:

The annual electric energy production by $\mathrm{PV} /$ Wind Hybrid system and PV only system are 16,102 $\mathrm{kWh} \mathrm{yr}^{-1}(100 \%)$ and $15,970 \mathrm{kWh} \mathrm{yr}^{-1}(100 \%)$, respectively, as shown in Table 6.

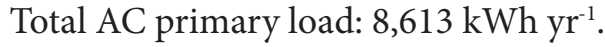

\section{Excess electricity}

In PV/Wind Hybrid system, the excess electricity occurred in all the months except in the months of July and August, and some days in June and September but occurred most in March (as can be clearly seen in Fig. 12) when the energy generated by the solar 


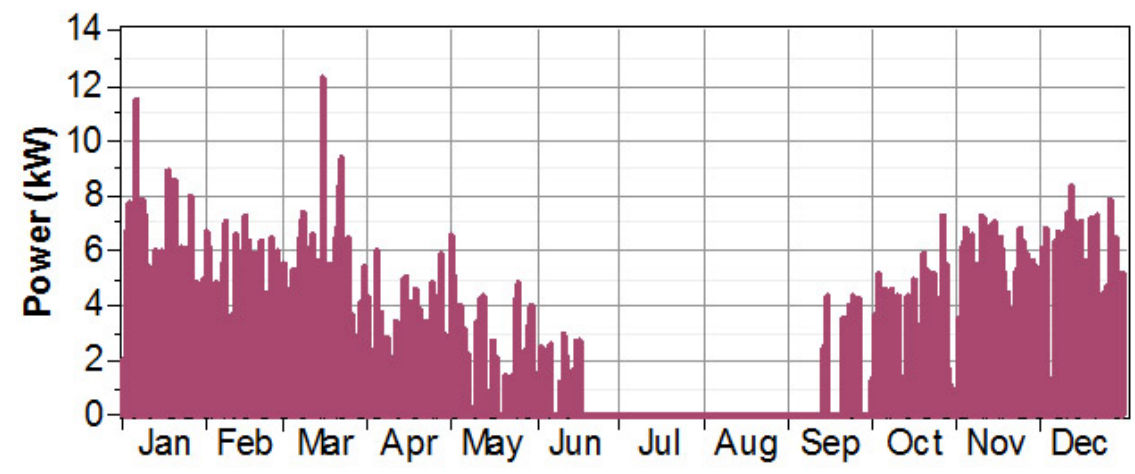

Figure 12 Excess Electricity generated by the Hybrid PV/Wind Energy System.

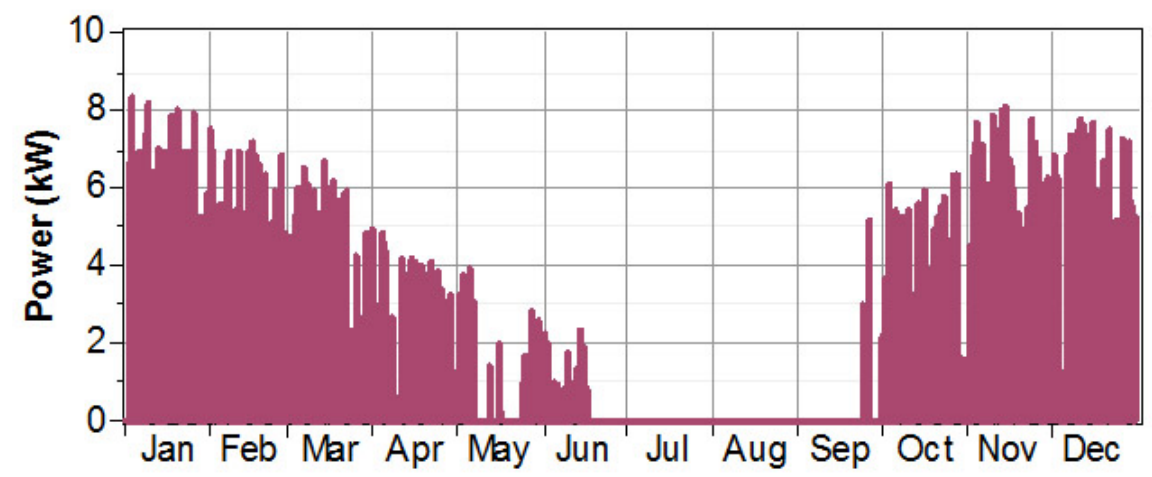

Figure 13 Excess Electricity generated by the PV Energy System.

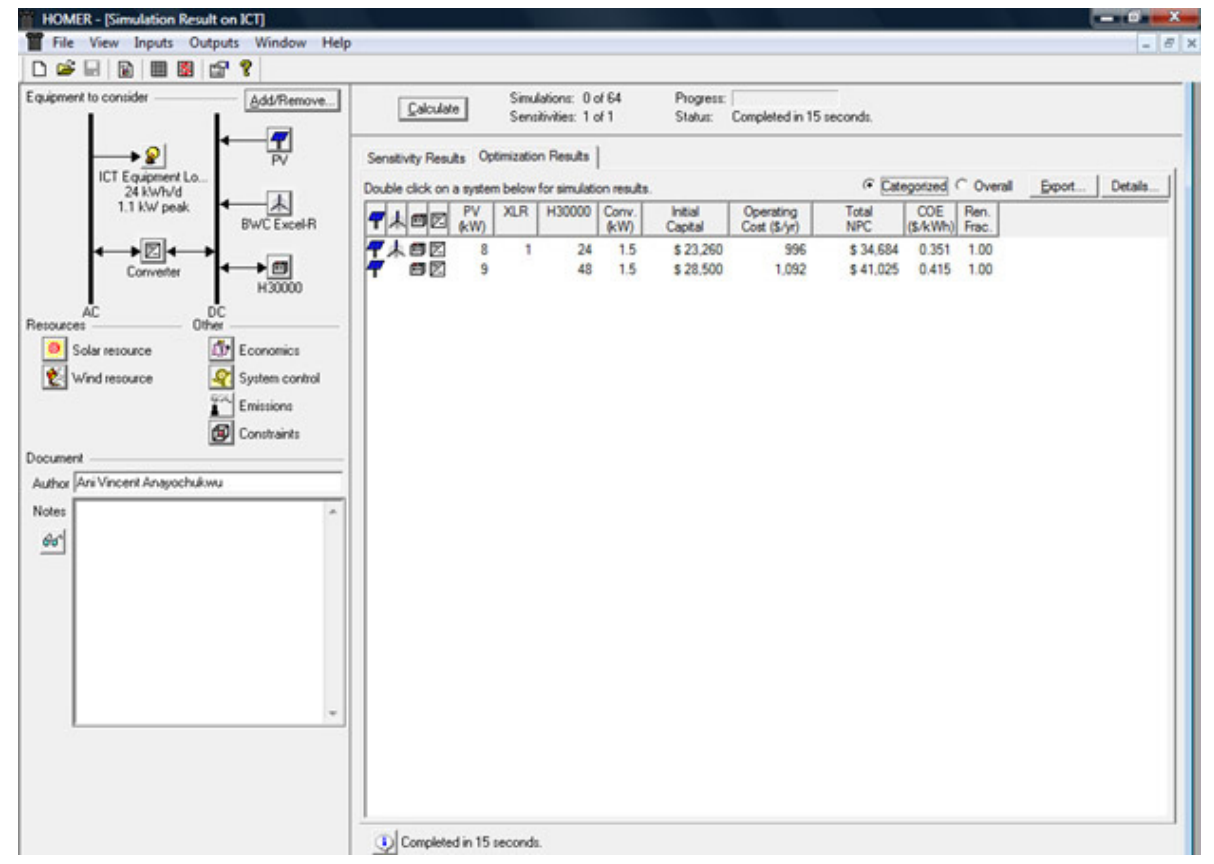

Figure 14 Overall optimization results of HOMER solutions. 
and wind are at the highest (Table 3); while in PV only system, the excess electricity occurred in all the months except in the months of July and August, and some days in May, June and September as shown in Fig. 13.

Excess energy $=$ Total energy Production $-($ Total losses + Total energy Consumption)

Excess energy from PV/Wind hybrid system = $[16,102-(2,237+8,613)]=5,252 \mathrm{kWh} \mathrm{yr}^{-1}$.

Excess energy from PV only system $=[15,970-$ $(2,331+8,613)]=5,026 \mathrm{kWh} \mathrm{yr}^{-1}$.

The PV/Wind Hybrid system has excess electricity of about 5,252 $\mathrm{kWh} \mathrm{yr}^{-1}$ (33\%) power supply, while the PV only system has excess electricity of about $5,026 \mathrm{kWh} \mathrm{yr}^{-1}$ (31\%). This excess electricity power supply is guaranteed in the location simulated in order to give room for future Center expansion. It can also be sold to nearby villages, factories, schools or facilities. The sale of this excess electricity will offer a promising approach for ICT facilities to finance operations and maintenance costs of the hybrid system.

In the energy system designed, 24 Hoppecke 24 OPzS 30000 batteries were used in Hybrid PV/Wind system, while in PV only system 48 Hoppecke 24 OPzS 30000 batteries were used as shown in Fig. 14. This shows that batteries are often sized smaller in a hybrid system than in a single-source system as claimed in [Ani and Nzeako, 2012b].

From the optimization results the best optimal energy system components ( $8 \mathrm{~kW}$ PV array, 1 unit $7.5 \mathrm{~kW}$ BWC Excel-R wind turbine, $1.5 \mathrm{~kW}$ inverter and 24 units Hoppecke $24 \mathrm{OPzS} 30000$ batteries) was determined for ICT Center located in a rural area of Kauru (Kaduna State) as shown in Fig. 14.

\section{Conclusion}

In this study, the proposed renewable Hybrid PV/ Wind system was simulated using HOMER software which resulted in two different topologies. These two different configurations (PV/Wind system and PV only system) were compared in terms of cost analysis and electricity generated. From the optimization results the best optimal energy system components (8 kW PV array, 1 unit $7.5 \mathrm{~kW}$ BWC Excel-R wind turbine, $1.5 \mathrm{~kW}$ inverter and 24 units Hoppecke 24 OPzS 30000 batteries) was determined for ICT Center located in a rural area of Kauru (Kaduna State). This system saves $\$ 6,341$ when compared with a PVonly system due to reduced number of battery units. The results also demonstrate that renewable hybrid systems have the potential of supplying electricity to ICT centres in a cost effective manner. Therefore, this study shows that there is a great promise for alternative renewable energy for power generation in Nigeria, if only the country could endeavour to explore and exploit these available resources.

\section{References}

Adejumobi, S.G.O., Akinboro, F.G. and Olajide, M.B. (2011). Hybrid solar and wind power: an essential for information communication technology infrastructure and people in rural communities. IJRRAS. vol. $9, \mathrm{n}^{\circ} 1$.

Ani, V.A. (2013a). Optimal energy system for single household in Nigeria. International Journal of Energy Optimization and Engineering. Publisher IGI Global.

Ani, V.A. (in Press). Optimal operational strategy for hybrid power generation at GSM base station site. International Journal of Energy Optimization and Engineering. Publisher IGI Global.

Ani, V.A. (2013b). Energy Optimization of Power Station for a Small Research Institute. International Journal of Energy Optimization and Engineering. Publisher IGI Global.

Ani, V.A. and Nzeako, A.N. (2012a). Energy optimization at GSM base station located at rural areas. International Journal of Energy Optimization and Engineering. vol.1, nº3.

Ani, V.A. and Nzeako, A.N. (2012b). The potential of Stand-Alone PV/Wind hybrid energy system for power supply to remote rural areas in Nigeria. International Journal for Clean Environment. vol. $13, \mathrm{n}^{\circ} 1-4,1-20$.

Ani, V. (2012). Energy optimization at telecommuni- 
cation base station sites. Unpublished doctoral dissertation, University of Nigeria, Nsukka. Nigeria.

Bala, E.J., Ojosu, J.O. and Umar, I.H. (2000). Government policies and programmes on the development of solar-PV Sub-sector in Nigeria. Nigerian Journal of Renewable Energy. vol. 8, nº1-2, 1-6.

Bagul, D., Salameh, Z. and Borowy, B. (1996). Sizing of a Stand-Alone hybrid Wind-Photovoltaic system using a three-event probability density approximation solar energy. Renewable Energy. vol. $56, n^{\circ} 1.4,323-335$.

Battery Experts. (2012). [Online]. http://www.batteryexperts.co.za/batteries_sealed.html

Celik, A.N. (2002). Optimization and techno-economic analysis of autonomous photovoltaic-wind hybrid energy systems in comparison to single photovoltaic and wind systems. Energy Conversion and Management. vol. 43, n $18,2453-2468$.

Chendo, M.A.C. (2002). Factors militating against the growth of the solars-PV industry in Nigeria and their removal. Nigerian Journal of Renewable Energy. vol. 10, nº1-2, 151-158.

Exchange rate for converting United States Dollar to Nigerian Naira: 1 USD $=161.49739$ NGN

http://themoneyconverter.com/USD/NGN.aspx http://themoneyconverter.com/USD/NGN. aspx\#exchange-rates

[Accessed on 07/17/2012]

Giraud, F., Salameh, Z.M. (2001). Steady-state performance of a grid-connected rooftop hybrid windphotovoltaic power system with battery storage. IEEE Trans Energy Convers. vol. 16, nº 1, 1-7.

HOMER 2.14, National Renewable Energy Laboratory (NREL), 617 Cole Boulevard, Golden,

CO 80401-3393, URL: http://www.nrel.gov/homer

[Accessed on 12/01/2012].

Kamaruzzaman, S., Azami, Z., Yusoff, A., Zulkifli, M.N., Razak, J.Ab., Muhammad, N.S. (2008). Optimal operational strategy for hybrid renewable energy system using genetic algorithms. WSEAS TRANSACTIONS on MATHEMATICS. vol. 7, $\mathrm{n}^{\circ} 4,130-140$.

Lambert, T. (2009). HOMER: The Hybrid Optimiza- tion Model for Electrical Renewables.

http://www.nrel.gov/international/tools/HOMER/ homer.html

[Accessed on 12/01/2009]

Lambert, T., Gilman, P., Lilienthal, P. (2006). Micropower system modeling with HOMER. In: Farret, F.A., Simoes, M.G., editors. Integration of alternative sources of energy, New York: John Wiley \& Sons.

Lau, K.Y., Yousof, M.F.M., Arshad, S.N.M., Anwari, M., Yatim, A.H.M. (2010). Performance analysis of hybrid photovoltaic/diesel energy system under Malaysian conditions. Energy. vol. 35, 3245-3255.

Markvart, T. (1996). Sizing of hybrid photovoltaicwind energy systems. Solar Energy. vol. 51, nº.4, $277-281$.

NASA, (2012) http://eosweb.larc.nasa.gov/

[Accessed on 14/02/2012].

NREL. (2005). National Renewable Energy Laboratory, HOMER Getting Started Guide Version

2.1

Pipattanasomporn, M. (2004). A Study of Remote Area Internet Access with Embedded Power Generation. Unpublished doctoral dissertation Virginia Polytechnic Institute and State University Alexandria, Virginia.

Shaahid, S.M. and El-Hadidy, M.A. (2003). Opportunities for utilization of stand-alone hybrid

(photovoltaic+diesel+battery) power systems in hot climates. Renewable Energy. vol. 28, nº11, 1741 1753.

Shaahid, S.M. and El-Hadidy, M.A. (2004). Prospects of autonomous/stand-alone hybrid (photovoltaic+diesel+battery) power systems in commercial applications in hot regions. Renewable Energy. vol. 29, n², $165-77$.

Solarshopnigeria, (2012).

http://www.solarshopnigeria.com/index.php/solarpv-modules/solarworld-modules/sunmodule-sw140-poly-r6a.html.

[Accessed on 14/08/2012].

Souissi, A., Hasnaoui, O. and Sallami, A. (2010). Optimal sizing of a hybrid system of renewable ener- 
gy for a reliable load supply without interruption. European Journal of Scientific Research. vol.45, $\mathrm{n}^{\circ} 4,620-629$.

Yang, H.X., Lu, L., Zhou, W. (2007). A novel optimization sizing model for hybrid solar-wind power generation system. Solar Energy. vol. 81, nº1, 7684 . 
